\title{
PROSES PENYEMBUHAN CEDERA JARINGAN LUNAK MUSKULOSKELETAL
}

\author{
Ukhti Jamil Rustiasari \\ Dep. Patologi Anatomi, Fakultas Kedokteran \\ Universitas Islam Indonesia, Yogyakarta \\ Email: ukhti.rustiasari@gmail.com
}

\begin{abstract}
Musculoskeletal system is the most frequently injured component, during exercises. Acute injuries caused by direct trauma and chronic injury due to the over use of soft tissues can cause damage in the musculoskeletal system either muscles, tendons or ligaments. Musculoskeletal injuries are often causing prolonged pain and reduced performance.

Musculoskeletal soft tissues remedial need to undergo a series of healing processes starting from acute inflammation, regenerations, repairing up to remodeling phase. Studies on cellular aspect engaged in healing process are playing important roles to create better understanding for determining appropriate intervention. This article discusses cellular aspects in musculoskeletal soft tissue injuries healing process related to appropriate therapy.
\end{abstract}

Key words: healing process, sport injuries, musculoskeletal, soft tissue

\begin{abstract}
ABSTRAK
Sistem muskuloskeletal adalah bagian yang paling sering mengalami cedera dalam olahraga. Cedera akut yang disebabkan oleh trauma langsung ataupun cedera kronis yang diakibatkan oleh overuse menyebabkan kerusakan jaringan lunak sistem muskuloskeletal baik pada otot, tendon maupun ligamen. Cedera muskuloskeletal seringkali menyebabkan nyeri berkepanjangan dan menurunkan performa olahragawan.

Jaringan lunak muskuloskeletal yang cedera akan mengalami serangkaian proses penyembuhan (healing process) dimulai dari fase inflamasi/radang akut, regenerasi dan perbaikan hingga fase remodelling. Kajian mengenai aspek seluler yang terlibat dalam proses penyembuhan berperan penting dalam memberikan pemahaman untuk menentukan intervensi yang tepat. Artikel ini membahas tentang aspek seluler pada tahapan-tahapan proses penyembuhan cedera muskuloskeletal yang dikaitkan dengan terapi yang sesuai.
\end{abstract}

Kata Kunci: healing process, cedera olahraga, muskuloskeletal, jaringan lunak.

\section{PENDAHULUAN}

Cedera otot merupakan salah satu cedera yang paling sering terjadi pada olahraga. Cedera muskuloskeletal dapat terjadi akibat trauma langsung seperti laserasi otot dan kontusio, maupun akibat trauma tidak langsung seperti strain. Lebih dari $90 \%$ cedera olahraga berupa kontusio maupun strain, sedangkan laserasi otot lebih jarang terjadi (Jarvinen et al, 2005). Pada trauma minor seperti strain, otot skelet dapat beregenerasi sempurna secara 
spontan. Namun pada kasus trauma berat proses penyembuhan otot dapat berlangsung tidak sempurna, mengakibatkan pembentukan jaringan fibrosis yang mengganggu fungsi otot (Laumonier \& Menetrey, 2016).

\section{A. Mekanisme penyembuhan cedera otot}

Secara umum mekanisme perbaikan cedera pada cedera otot terbagi dalam 3 tahap yaitu fase destruksi/ degenerasi dan inflamasi/peradangan, fase regenerasi/ perbaikan dan fase remodelling/ renovasi. Tahapan fase perbaikan dan renovasi seringkali berjalan bersamaan.

\section{Fase degenerasi dan inflamasi}

Proses degenerasi dan inflamasi terjadi pada beberapa hari awal setelah cedera. Proses ini dicetuskan karena adanya kerusakan sarkolema. Kemudian terjadi influks kalsium yang tidak teregulasi ke dalam sarkolema yang cedera. Jumlah kalsium dalam sitoplasma yang berlebihan menyebabkan enzim protease dan hidrolase teraktivasi sehingga terjadi kerusakan sel otot serta mengaktivasi berbagai enzim yang mendorong terproduksinya substansisubstansi mitogenik bagi sel otot dan sel imunitas (Tidball et al, 2011; 2005).

Hematoma terbentuk ketika terjadi kematian sel otot. Bersamaan dengan ini, sel-sel inflamasi hadir di area yang rusak karena robeknya pembuluh darah. Ketika terjadi kerusakan pada sarkolema, berbagai eikosanoid terutama prostaglandin, prostasiklin, leukotrien dan tromboksan dikeluarkan (Smith, 2004). Eikosanoid berperan dalam pengaturan vasodilatasi, aktivitas kemotaktik dan peningkatan permeabilitas endotel vaskular yang menyebabkan masuknya sel-sel inflamasi ke daerah cedera (Smith, 2004; Tidball, 2005).

Neutrofil merupakan leukosit PMN yang pertama kali mendatangi daerah cedera. Neutrofil akan melakukan fagositosis untuk menghilangkan komponen-komponen hasil cedera dengan cara melepaskan lisosom protease yang akan mendegradasi protein. Neutrofil juga membentuk ROS untuk menghindari terjadinya eksaserbasi cedera (Tidball, 2005). Neutrofil kemudian mensekresi sejumlah besar molekul-molekul proinflamasi faktor-faktor pertumbuhan dalam rangka menciptakan lingkungan mikro yang kemoatraktif bagi sel-sel inflamasi lainnya seperti monosit maupun makrofag.

Neutrofil kemudian digantikan oleh monosit dalam waktu beberapa jam setelah cedera. Monosit kemudian akan berubah menjadi makrofag. Makrofag memiliki 2 fungi utama, yaitu menghilangkan serabut otot yang nekrosis melalui proses fagositosis. Fungsi lainnya adalah bersama 
fibroblast, makrofag juga menghasilkan sinyal kemotaktik seperti faktor-faktor pertumbuhan, sitokin dan kemokin (Baoge et al, 2012).

Dua jenis makrofag yang telah teridentifikasi selama proses penyembuhan cedera adalah makrofag MI dan M2. Makrofag M1 diketahui merupakan makrofag pro-inflamasi yang hadir pada 24-48 jam di daerah cedera. Makrofag ini berperan dalam melisiskan sel, menghilangkan debris selular melalui proses fagositosis dan menstimulasi proliferasi mioblast. Berbeda dengan makrofag M2 yang dikenal sebagai makrofag anti-inflamasi, sel ini bekerja pada 48-96 jam setelah cedera dengan menurunkan respon inflamasi yang terjadi dan mendukung terjadinya proses perbaikan sel otot dengan membentuk formasi miotubul (Tidball dan WehlingHenricks, 2007). Makrofag juga diketahui berperan dalam proses perbaikan jaringan yang rusak dengan mensekresi berbagai molekul pro-regenerasi. Diantaranya adalah insulin-like growth factor (IGF) dan fibroblat growth factor (FGF) serta transforming growth factor- $\beta$ (TGF- $\beta$ ).

\section{Fase regenerasi dan perbaikan}

Regenerasi sel otot dimulai pada 45 hari pertama setelah kerusakan dan memuncak setelah 2 minggu. Kemudian secara gradual akan menurun pada 3-4 minggu setelah terjadi kerusakan. Fase ini terdiri atas 2 tahap, yaitu regenerasi sel otot dan pembentukan jaringan ikat atau fibrosis.

Sel otot merupakan sel post-mitosis yang tidak memiliki kapasitas untuk membelah. Pada keadaan cedera, sel otot yang rusak tidak mampu diperbaiki tanpa kehadiran sel prekursor miogenik yaitu sel satelit. Tahap regenerasi ini dapat terjadi karena masih adanya sel-sel satelit yang berada di bawah lamina basalis sel otot. Pada sel otot dewasa, sel satelit berada pada status istirahat. Jumlah sel satelit ini bergantung pada usia, lokasi dan tipe sel otot. (Relaix dan Zammit, 2012)

Ketika otot mengalami cedera, sel satelit teraktivasi oleh faktor-faktor pertumbuhan dalam 18 jam setelah cedera sebagai respon terhadap stimulus kimiawi. Regenerasi serabut otot hanya dapat terjadi ketika sel satelit teraktivasi. Aktivasi ini menyebabkan sel satelit berproliferasi dan berdiferensiasi menjadi mioblast. Mioblast kemudian akan membentuk miotubul baru atau bergabung dengan serabut otot yang rusak, mengisi area antara serabut otot yang rusak dan kemudian menjadi serabut otot fungsional yang matur (Laumonier and Menetrey, 2016).

Di saat yang bersamaan, terjadi pembentukan jaringan ikat oleh fibrin dan fibronektin yang berasal dari darah akibat pembentukan hematoma pada awal 
kerusakan jaringan. Kehadiran fibrin dan fibronektin pada area kerusakan akan menginisiasi terbentuknya matriks ekstraselular yang akan diisi secara cepat oleh fibroblast (Darby et al, 2016; Ménétrey, 2000).

Matriks ekstraseluler mengandung faktor-faktor pertumbuhan yang menjadi aktif ketika terjadi kerusakan jaringan. Beberapa faktor pertumbuhan tersebut adalah FGF, IGF-2, TGF- $\beta$, hepatocyte growth factor (HGF), tumor necrosis factor- $\alpha$ (TNF- $\alpha)$, dan IL-6 (interleukin-6). Faktor-faktor ini akan memanggil dan mengaktivasi fibroblast yang kemudian akan menghasilkan kolagen, yang berkontribusi dalam regenerasi jaringan. Mereka juga menghasilkan sinyal yang dapat mengaktivasi proliferasi dan diferensiasi sel satelit (Pedersen et al, 1998; Relaix dan Zammit, 2012).

Jaringan ikat yang terbentuk pada fase ini akan memberikan dasar bagi fibroblast untuk mengisi jaringan granulasi serta memberikan kekuatan pada otot untuk menahan kontraksi. Namun dalam kasus proliferasi fibroblast yang berlebih, jaringan parut dapat terbentuk di antara otot yang rusak. Hal ini tidak hanya mengganggu proses perbaikan, tetapi juga menghambat proses regenerasi otot dan menyebabkan pemulihan fungsional otot pada fase selanjutnya menjadi tidak sempurna (Baoge et al, 2012).
Kerusakan yang terjadi akibat cedera dapat mengakibatkan cabangcabang saraf intramuskular menjadi rusak. Sel-sel otot dapat mengalami denervasi yang dapat mempengaruhi proses penyembuhan. Proses perbaikan cedera dikatakan selesai sempurna ketika sel otot yang cedera mengalami regenerasi lengkap dan terinervasi dengan baik. Terbentuknya celah neuromuskular memiliki peran penting dalam maturitas dan kemampuan fungsional otot yang regenerasi. Kehadiran celah neuromuskular ini dapat terlihat pada otot-otot yang regenerasi pada 2-3 minggu setelah cedera (Rantanen, 1995).

\section{Fase remodelling}

Fase ketiga ini terdiri atas proses remodelling yang dimulai 2-3 minggu setelah onset cedera dan dapat bertahan hingga 1 tahun atau lebih. Fase ini bertujuan untuk menghasilkan maksimal kekuatan regangan sel otot melalui proses reorganisasi, degradasi dan resintesis matriks ekstraselular. Fase ini ditandai dengan terbentuk sel-sel otot yang matur dengan perubahan pada matriks ekstraselular dan resolusi dari inflamasi awal serta terjadi reorganisasi jaringan ikat fibrosis serta kontraksi jaringan (Jarvinen et al, 2005).

\section{B. Penatalaksanaan pada Cedera Otot}

Tujuan pengobatan pada cedera jaringan lunak harus mempertimbangkan 
proses penyembuhan alami. Berbagai bentuk penatalaksanaan dilakukan pada fase akut maupun kronik saat terjadi cedera muskuloskeletal. Hal ini bertujuan untuk meminimalisasi terjadinya kerusakan lebih lanjut, menghilangkan rasa nyeri dan spasme, mengurangi kejadian perdarahan dan edema serta mendukung penyembuhan.

\section{Fase inflamasi akut}

Rehabilitasi yang dilakukan pada fase ini bertujuan untuk mengontrol pembengkakan dan mengendalikan nyeri dengan metode RICE serta tatalaksana farmakologik. Selain itu, pada fase ini juga mulai dilakukan latihan-latihan yang digunakan untuk mengembalikan ROM (range of movement).

\section{RICE (Rest, Ice, Compression and Elevation)}

Setelah terjadi cedera pada otot, direkomendasikan penerapan prinsip RICE segera mungkin. Penatalaksanaan ini bertujuan untuk meminimalisasi pembentukan hematoma, edema interstitial, mengurangi risiko terjadinya jaringan iskemia pada area otot yang rusak. Hal ini diharapkan dapat menurunkan pembentukan jaringan fibrosis (Menetrey, 2000). Kompres es dilakukan secara sebentar-sebentar selama 15-20 menit dengan interval 30-60 menit sekali. Hasil penelitian Schaser menunjukkan bahwa kompres es pada area cedera sebaiknya dilakukan pada jangka waktu yang cukup panjang (6 jam) untuk mendapatkan efek yang nyata dalam mengurangi perdarahan dan nekrosis jaringan. Perpanjangan periode kompres es ini dapat meningkatkan sirkulasi dan mengurangi perdarahan (Schaser et al, 2007).

Efektifitas aplikasi RICE belum terbukti pada studi RCT. Namun demikian, terdapat bukti-bukti ilmiah dari sturi eksperimental terhadap penerapan komponen RICE. Penerapan imobilisasi segera setelah cedera dapat mencegah terjadinya retraksi sel otot yang rusak, mengurangi pembentukan ukuran hematoma, hingga akhirnya mampu mengurangi ukuran pembentukan jaringan fibrosis (Jarvinen et al, 2005).

Periode imobilisasi pada cedera otot dengan tipe shearing diperlukan untuk memberikan waktu agar terbentuk jaringan granulasi lebih cepat di antara otot yang cedera dan menghubungkan antara ujung otot yang cedera untuk mendapatkan kekuatan yang diperlukan untuk menahan kontraksi yang diinduksi pada jaringan yang beregenerasi tanpa terjadinya ruptur. Jika imobilisasi pada awal terjadinya cedera tidak dilakukan, maka dapat terjadi ruptur pada cedera otot yang telah ada yang diikuti oleh pembentukan skar (Jarvinen et al, 2005). 
Efek penggunaan kompres es dikaitkan dengan pemakaian krioterapi yang menunjukkan terjadinya pembentukan hematoma yang secara signifikan lebih kecil, berkurangnya peradangan dan nekrosis jaringan serta mempercepat proses regenerasi (Schaser et al, 2007). Namun penerapan kompresi es ini masih menjadi perdebatan, karena proses ini mengurangi jumlah aliran darah intramuskular ke area cedera. Komponen terakhir yaitu penggunaan teknik elevasi area cedera didasarkan atas tekanan hidrostatik yang akan menurun pada area yang berada di atas posisi jantung, sehingga akan mengurangi terjadinya akumulasi cairan interstitial (Jarvinen et al, 2013).

\section{Terapi Farmakologi}

A. Obat anti inflamasi non steroid (NSAIDs)

Penggunaan obat anti inflamasi non steroid (NSAIDs) dapat direkomendasikan untuk diberikan pada fase akut, meskipun hal ini masih menjadi perdebatan. Respon inflamasi merupakan fase yang sangat penting dalam proses penyembuhan cedera otot. NSAIDs diketahui dapat mengganggu aksi makrofag, membatasi fungsi fagositosis, menghambat produksi faktor-faktor pertumbuhan yang bertanggung jawab dalam proses regenerasi (Mishra et al, 1995). NSAIDs dapat menghambat kemotaksis sel inflamasi yang diperlukan dalam proses perbaikan dan remodelling (Rahusen et al, 2004). Sehingga terjadinya inhibisi respon inflamasi dapat menyebabkan pemulihan fungsional otot menjadi tidak sempurna.

Hasil penelitian lainnya menunjukkan bahwa penggunaan NSAIDs pada waktu yang singkat difase awal penyembuhan menyebabkan adanya penurunan reaksi sel-sel inflamasi tanpa mempengaruhi proses penyembuhan yang terjadi, juga pada kekuatan regangan serta kemampuan sel otot yang cdera untuk berkontraksi. NSAIDs juga tidak menyebabkan penundaan proses regenerasi sel otot (Jarvinen et al, 1992).

Rekomendasi penggunaan NSAIDs diberikan diatas 48 jam setelah cedera, dalam rangka memberikan efek analgetik dan mengurangi pembengkakan dengan menekan respon inflamasi akut. NSAIDs memiliki efek menguntungkan dengan mencegah terjadinya respon inflamasi akut yang berlebihan yang dapat mengakibatkan edema, anoksia hingga kematian sel (Paoloni et al, 2009). Walaupun demikian, penggunaan obat ini pada jangka panjang (lebih dari 7 hari) juga tidak disarankan karena dapat memperlambat proses regenerasi otot dengan menginaktivasi proses proliferasi dan diferensiasi sel satelit serta menginhibisi produksi faktor-faktor 
pertumbuhan (Rahusen et al, 2004). NSAIDs juga diketahui dapat mengurangi kekuatan kontraksi sel otot.

B. Obat Glukokortikoid

Glukokortikoid seperti injeksi steroid seringkali digunakan sebagai pilihan obat-obatan pada cedera muskuloskeletal Meskipun dilaporkan suntikan kortikosteroid intramuskular memberikan keuntungan, hasil studi eksperimental menunjukkan bahwa terdapat penundaan eliminasi hematoma dan area nekrosis pada jaringan otot, terjadinya kemunduran proses regenerasi otot, dan akhirnya mengurangi kekuatan biomekanik otot yang cedera (Beiner et al, 1999). Berdasarkan hal ini, penggunaan obat ini tidak direkomendasikan pada fase akut.

\section{Fisioterapi}

Pada hari kedua atau ketiga fase akut sering timbul keterbatasan gerak yang terutama disebabkan karena rasa sakit. Pada kondisi ini, modalitas yang dapat mengurangi rasa sakit seperti stimulasi elektrik dapat digunakan secara rutin pada setiap sesi pengobatan. Pasien juga disarankan untuk mulai melakukan latihan mobilisasi aktif hingga batas nyeri (Prentice, 2011).

Mobilisasi dini mempercepat pertumbuhan kapiler dan meningkatkan regenerasi serabut otot. Otot yang menyembuh juga dapat kembali mencapai kekuatan semula dengan lebih cepat. Namun mobilisasi dini juga memiliki kekurangan, diantaranya adalah kemungkinan terjadinya ruptur ulang maupun pembentukan jaringan skar yang lebih luas. Oleh karena itu, latihan aktif harus dimulai secara bertahap. Bentuk latihan dapat diawali dengan latihan isometrik hingga batas nyeri untuk memulai pengembalian ROM (Jarvinen, 2005).

\section{Fase regenerasi dan perbaikan}

Pada fase ini biasanya pembengkakan sudah mulai menghilang, namun daerah cedera masih dapat terasa nyeri ketika disentuh meskipun rasa nyeri tidak seperti pada fase sebelumnya. Rasa nyeri dirasakan berkurang baik pada saat gerakan pasif maupun aktif. Pasien dapat memulai program rehabilitasi yang bertujuan untuk meningkatkan kekuatan otot dan memperbaiki fleksibilitas otot. Bentuk rehabilitasi yang dapat dilakukan adalah latihan isotonik yang dapat dilakukan secara bertahap yang kemudian dapat dilanjutkan dengan latihan isokinetik. Seperti pada fase akut, modalitas dapat digunakan untuk mengontrol nyeri dan pembengkakan. Modalitas berupa stimulasi eletrik dapat membantu mengendalikan nyeri, memperbaiki ROM dan kekuatan otot (Prentice, 2011). 


\section{Fase Remodelling}

Fase ini merupakan fase terpanjang pada penyembuhan cedera, dimana fase ini dapat berlangsung hingga beberapa tahun, bergantung pada tingkat keparahan cedera. Penatalaksaan pada fase ini adalah dengan melakukan rehabilitasi yang bertujuan agar pasien mendapatkan kembali kemampuan fungsional awal sehingga dapat beraktivitas seperti semula. Bentuk latihan yang intens untuk mengembalikan ROM dan latihan penguatan otot untuk memfasilitasi remodelling jaringan dan mengembalikan kesejajaran posisi tulang dan sendi dapat dilakukan pada fase ini.

Terapi modalitas panas dapat bermanfaat pada fase remodelling. Penggunaan modalitas panas yang lebih invasif, ultrasound atau diatermi dapat digunakan untuk meningkatkan sirkulasi pada jaringan yang lebih dalam. Pemijatan dapat dilakukan untuk mengurangi nyeri dan meningkatkan sirkulasi. Peningkatan aliran darah berfungsi untuk mengantarkan nutrisi-nutrisi penting ke area cedera yang diperlukan dalam proses penyembuhan dan meningkatkan sistem limfatik yang membantu dalam drainase zat buangan (Prentice, 2011).

\section{KESEIMPULAN}

Proses penyembuhan pada cedera otot terdiri atas 3 fase yaitu fase degenerasi dan inflamasi akut dimana terjadi aktivasi sel-sel inflamasi dan pengeluaran sitokin pro-inflamasi, fase regenerasi dan perbaikan yang ditandai dengan aktivasi sel satelit dan proliferasi fibroblast serta fase remodelling yang ditunjukkan dengan maturasi sel-sel otot serta reorganisasi matriks ekstraseluler. Ketiga fase ini terjadi secara berurutan dan kontinyu, namun dapat terjadi secara tumpang tindih.

Penatalaksanaan cedera otot diawali dengan RICE untuk mengontrol inflamasi yang terjadi, mengurangi rasa nyeri serta mengurangi risiko terjadinya jaringan iskemia pada area otot yang rusak. Rekomendasi penggunaan NSAIDs dapat diberikan diatas 48 jam setelah cedera, dalam rangka memberikan efek analgetik dan mengurangi pembengkakan dengan menekan respon inflamasi akut. Sedangkan obat-obat glukorkortikoid tidak direkomendasikan pada fase inflamasi akut.

Fisioterapi dan rehabilitasi dapat dilakukan sejak hari ketiga fase inflamasi hingga fase remodelling. Bentuk latihan dapat dimulai secara bertahap yang diawali dengan latihan isometrik hingga batas nyeri untuk memulai pengembalian ROM. Latihan ini bertujuan untuk mempercepat pertumbuhan kapiler dan meningkatkan regenerasi serabut otot. Pada fase regenerasi, bentuk latihan dapat dilanjutkan dengan latihan isotonik hingga isokinetik yang bertujuan untuk 
meningkatkan kekuatan otot dan memperbaiki fleksibilitas otot. Pada fase remodelling bentuk latihan dapat berupa latihan penguatan otot yang lebih intens agar pasien mendapatkan kembali kemampuan fungsional awal sehingga dapat beraktivitas seperti semula.

Modalitas alat berupa stimulasi eletrik dapat diberikan disetiap akhir sesi latihan pada fase regenerasi. Hal ini bertujuan untuk membantu mengendalikan nyeri, memperbaiki ROM dan kekuatan otot. Pemijatan dan modalitas panas seperti ultrasound dan diatermi dapat diberikan pada fase remodelling bertujuan untuk mengurangi nyeri serta meningkatkan laju sirkulasi darah dan limfatik.

\section{DAFTAR PUSTAKA}

Baoge L, Van Den Steen E, Rimbaut S, Wtvrouw E, Almqvist KF, Vanderstraeten G, et al. 2012. Treatment of SkeletalMuscle Injury: A Review. ISRN Orthopedics. 2012; 2012:1-7.

Beiner JM, Jokl P, Cholewicki J, Panjabi MM. 1999. The effect of anabolic steroids and corticosteroids on healing of muscle contusion injury. Am J Sports Med. 1999. 27(1):2-9.

Darby IA, Zakuan N, Billet F, Desmouliere A. 2016. The myofibroblast, a key cell in normal and pathological tissue repair. Cell Mol Life Sci. 2016;73(6):1145-57.

Jarvinen M, Lehto M, Sorvari T. 1992. Effect of some anti-inflammatory agents on the healing of ruptured muscle. An experimental study in rats. J Sports Traumatol. 1992;14:1928.

Jarvinen TAH, Jarvinen TLN, Kaariainen M, Kalimo H, Jarvinen M. 2005. Biology of muscle trauma. Am J Sports Med. 2005;33:745-66.

Jarvinen TAH, Jarvinen M, Kalimo $\mathrm{H}$. 2013. Regeneration of injured skeletal muscle after the injury. Muscles, Ligaments and Tendons Journal. 2013;3(4):337-45.

Laumonier and Menetrey. 2016. Muscle injuries and strategies for improving their repair. Journal of Experimental Orthopaedics. 2016;3:15.

Mishra DK, Friden J, Schmitz MC, and Lieber RL. 1995. Antiinflammatory medication after muscle injury: a treatment resulting in short-term improvement but subsequent loss of muscle function. Journal of Bone and Joint Surgery A. 1995;77(10):1510-9.

Pedersen BK, Rohde T, Ostrowski K. 1998. Recovery of the immune system after exercise. Acta Physiol Scand. 1998;162:325-32.

Paoloni J, Milne C, Orchard J, and Hamilton B. 2009. Nonsteroidal antiinflammatory drugs (NSAIDs) in sports medicine:guidelines for practical but sensible use. British Journal of Sports Medicine. 2009;43(11):863-5.

Prentice WE. 2011. Rehabilitation techniques for sports medicine and athletic training. 5th ed. Ney York: McGraw Hill.

Rahusen FTG, Weinhold PS, and Almekinders LC. 2004. Nonsteroidal anti-inflammatory drugs and 
acetaminophen in the treatment of an acute muscle injury. American Journal of Sports Medicine. 2004;32(8):1856-9.

Rantanen J, Ranne J, Hurme T, Kalimo H. 1995. Denervated segments of injured skeletal muscle fibers are reinnervated by newly formed neuromuscular junctions. J Neuropathol Exp Neurol. 1995;54(2):188-94.

Relaix F, Zammit PS. 2012. Satellite cells are essential for skeletal muscle regeneration: the cell on the edge returns centre stage. Development. 2012;139(16):2845-56.

Tidball JG. 2005. Inflammatory processes in muscle injury and repair. Am $\mathrm{J}$ Physiol Regul Integr Comp Physiol. 2005;288:R345-53.

Tidball JG, Wehling-Henricks M. 2007. Macrophages promote muscle membrane repair and muscle fibre growth and regeneration during modified muscle loading in mice in vivo. J. Physiol. 2007;578:327-36.

Tidball JG. 2011. Mechanisms of muscle injury, repair, and regeneration. Compr Physiol. 2011;1(4):2029-62.

Schaser KD, Disch AC, Stover JF, Lauffer A, Bail HJ, Mittlmeier T. 2007. Prolonged superficial local cryotherapy attenuates microcirculatory impairment, regional inflammation, and muscle necrosis following closed soft tissue injury in rats. Am J Sports Med. 2007;35:93-102.

Smith LL. 2004. Tissue trauma: the underlying cause of overtraining syndrome? J Strength Cond Res. 2004;18:185-93. 